\title{
New Paths of the History of Justice and Security Institutions in Latin America
}

\author{
Osvaldo Barreneche* and Agustín Casagrande \\ Universidad Nacional de La Plata, Argentina
}

\section{Abstract}

In the research carried out in Latin America, the history of justice, on the one hand, and the history of security or law enforcement institutions, on the other, often failed to find common grounds in terms of focus, approach, problems, methodologies and even historical periods around which they mostly centered. After several years each current's searching and making contributions on its own, today, a new coincidence takes place within the sphere of Latin American political history, as renewed in turn by recent contributions, which finds in the 19th century the right spot for thematic crossovers. This article focuses around this specific aspect of the field: surveying the thematic contributions and convergence which, within the historiography, signalize a new meeting point. We would like to argue that it is precisely from here that thematic and research lines are developed and that we will witness the next contributions arise from them.

\section{Starting Points and Expectation Horizons}

About 20 years ago, a number of academic meetings took place in London, Puerto Rico, Buenos Aires and New Haven, the results of which were gathered in several collective volumes. ${ }^{1}$ These meetings were places of confluence and starting points for various research lines developing around the history of Latin American justice and security institutions, both within the English-speaking and the Latin American university spheres. Since then, the study of law and justice has become part of Latin America's social, intellectual, political and cultural history, not merely as the History of Law which had been prevalent until then. Law ceased to be seen as a fixed regulatory web and began to be considered as a conflict arena. Its analysis, therefore, cannot be reduced to just the study of legislation. It must also take into account the relations with other social fields, the interactions between the different government actors and the civil society, as well as the tensions caused by the convergence of purely legal logical and other rationalities (whether these be professional, bureaucratic, scientific, corporate, etc.), which are part of the daily work of security and justice administration agencies.

The "New Legal History" was then beginning to consolidate, with its thematic agenda rapidly diversifying and becoming more specific within different academic spheres. In fact, as a consequence of the interest that the new field recalled among the researchers, the matters were broadened, bringing, as expected, some problems in establishing a unidimensional perspective for diverse objects of study. It is not surprising, then, that in the research carried out in Latin America, the history of justice, on the one hand, and the history of security or law enforcement institutions, on the other, often failed to find common grounds in terms of focus, approach, problems, methodologies and even historical periods around which they mostly centered. ${ }^{2}$ Nevertheless, the new discussions, instead of dissolving the first encounter, reinforced the field through a dialogical exercise of criticism.

Precisely, after several years each current's searching and making contributions on its own, nowadays, we are witnessing a historiographic moment of reunion between the history of justice and the history of security and law enforcement institutions. However, this new 
coincidence has found a new ground, not anymore inside the criticism against legal history, but it takes place within the Latin American political history sphere, as renewed in turn by recent contributions, which finds in the 19th century the right spot for thematic crossovers. ${ }^{3}$

This article is not a survey of all the historiography of justice and security institutions in Latin America. Instead, we will focus on the themes and scholarship that signal the meeting point of diverse traditions that are encompassed in the attempt of showing the complexity of studying governmental institutions in times of changing orders. We would like to argue that it is precisely from here that thematic and research lines are developed and that we will witness the next contributions arise from them.

\section{Dialog and Tradition: Critical Legal History and New Legal History}

The new legal history flourished in the midst of a critical intersection with the history of law. However, it also prospered from the need to suppress the explanation of the legal phenomenon as a mere reflection of the economic system. Thus, the new characterization of the discipline derived from rescuing the productive role that law has as a place for social construction and negotiation; from which point, there was a methodological turn toward anthropology and cultural studies. ${ }^{4}$

The greatest tension, though, was with the traditional legal history practiced by lawyers in law Faculties. Methodologically analyzed, the New Legal History approach challenged the notion of the normalizing power of law and strives to make close-range observations of the institutions as a field where certain actors' interaction and struggle is to take place. Thus, gazing on other sources (criminal courts decisions, books of prisons, trials records, criminal literature, newspapers, memories, etc.), it managed to find once again the practices that created a legal experience, which was a vehicle for extensive political actions that overflowed the logics inscribed in abstract normativity. All this, among other things, enabled the recovery of state cultures crossings and popular use.

Contextually, that revision of topics and methods could be the result of the influence of scholarships out of North America, specially taking in consideration the new approaches realized during the 1970s and 1980s. Nevertheless, at that time, though intellectually unrelated, there was also a deep revision of the ways in which the legal phenomenon was thought about within the European legal history sphere. The latter, though, never proposed such a redefinition of the object and sources as the New Legal History would, but rather a redefinition of the theoretical and category framework through which one could gain access to the pre-modern and contemporary study of law. As a result of the observation of the state-nation crisis, (perceived in the consolidation of supranational levels of decisions - international courts, economic and monetary unions, revival of local nationalisms inside the traditional state-nations), a new legal history - called "critical history of law" - started to rediscover some structures of political thought that had been obscured, when not denied, by using state-modern legal-political concepts: administration, law, state. With this, there was a rediscovery of a distinctive juridical dimension, which displays other political institutions as structuring elements that ensured community government in the past.

Both trends, which revised the classic modes of operation in the history of legal ideas, traveled through parallel paths and have only met very recently, steadily invading the writing of a history of justice and security institutions in Latin America. However, despite their agreement on an anthropological interest, their reference points and the various interests determining their methodologies, objects, timing and areas of research are not altogether similar.

\section{Jurisdictionalism (16th-18th Century): from Social History to Political History}

In historiographic practice, the time limit selected for the observation of various issues has a key influence on the theoretical framework and the methodology displayed to deal with the sources. 
Scholarly developments in the social history of justice in colonial Latin America (16th-18th centuries) began to distinguish that instead of having a state form of government, the exercise of the power was realized under the ubiquitous figure of jurisdictional power, which was related with the crucial figure of the "judge". Therefore, it was not the legislator rather the local magistracy who was in charge of bringing order to the community, by appalling not only to the law but, principally, to the local custom, the theological knowledge, practical books and practices of the neighbors.

It was there that the critical history of law quickly extended to the studies of Latin American social and political history. The contributions made by the group gathered around the Quaderni Fiorentini, mainly those by Paolo Grossi, Bartolomé Clavero and António M. Hespanha presented a scheme for understanding a pre-modern order which was different from that put forward by contemporary legal and political languages. ${ }^{5}$ Such radical criticism led to the dismantling of contemporary logics, thus introducing in its place a constitutional order which allocated the foundation of power under the paradigm of the government by way of justice. ${ }^{6}$

The Spanish crown sought to dispense justice and establish peace through a "jurisdictional order" administered by the judicial apparatus. Moreover, political institution revision caused the old traditions connected with the understanding of a non-state culture, which acted by way of justice among neighbors and family members: religion and domestic government, to be dusted off. ${ }^{7}$ As a consequence, two effects can be pointed out which would shape this historiographic line. The first was the centrality gained by the study of 'justice' to understand the political phenomenon. Therefore, the studies about the 'history of justice' for the cited period reopened a dialog which was closer to political history than to social history. ${ }^{8}$ The second is subsequent to the first since, when seeing the political world confused inside the legal world, the precision of the knowledge included in legal categories from the sources acquired a predominant role. History, then, was coated with highly conceptual depth when revisiting the study of justice and political institutions - whether these be domestic, jurisdictional or otherwise - searching within the sources for a relationship between social and constitutional experience, by analyzing languages and setting aside methodologies which were closer to sociology, like statistics.

The reconsideration of the conceptuality that framed the political order of the Spanish and Portuguese Crowns had an immediate impact in the Latin American historiography. In the case of Mexico, such frame was materialized in the revision of work hypotheses and the redefinition of the law-legal culture relation, which is expressed in the Mexican Legal History methodological field. ${ }^{9}$ In this way, under this internal reception of the jus-historical field, the dialog with social history came closer and became more prolific, social history thus receiving this new critical legal history trend. ${ }^{10}$ This also becomes evident in the close collaboration between legal and social historians, which can be appreciated in studies co-written by them. ${ }^{11}$ All of this has enabled a series of publications which turn to the social history of justice through very interesting approaches, such as legal archeology, cultural studies and social history. In any event, the Mexican root puts forward a particular piece of information: a reading and re-signification of political experience which does not stop at the studies on pre-modern world, but extends its timeline to the 19th and 20th centuries, which is being discussed in other academic circles.

In Argentina, the study of the justice - without a state - also provided a form of criticism to national histories. Thus, when the nation as a unit vanished, the rescue of the local government as the structuring principle for the political order reappeared. ${ }^{12}$ This naturally resulted in the multiplication of small-scale studies portraying justice as a local phenomenon and allowing for a contrast between the different experiences of the various territories which make up the nation-state at present. This localization can be appreciated in several compilations, which cross over various spaces centered around certain legal-political problems. ${ }^{13}$ Within this line, we can highlight the rewriting of criminal-jurisdictional history, which allowed for the reconsideration of the impact of Bourbon reforms, showing social control through government policies of 
"Cabildo" justice and the role of the household as the structuring element of order. ${ }^{14}$ The topics spread, not only to criminal matters, but also to the creation of a space culture as a governing device and as educator of civil and criminal jurisdictions. ${ }^{15}$

These tendencies can also be found in Chile, where through new publications with solid foundations on French social history, a dialog began with the already consolidated Chilean legal-historical tradition. The former, wandering precisely around the edges of legal critical history and social history, searched for those minor records of judicial conflicts in the Viceroyship world of the Bourbon's, which the latter did not pay previous attention to.

Historians of Rio de la Plata have taken in consideration the marginal character of that space in relation to the Spanish metropolis, which provoked a closer dialog with judicial sources produced by courts and judges at local levels. This legal arena, however, is quite vague in other spheres due to the preeminence and political-judicial weight that "Audiencias" and other higher courts of law used to have. In the case of Peru, apart from Sarah Chambers's contributions in the passage toward citizenship, ${ }^{16}$ analyses started to focus on the judicial exercise of the audience in Lima, upon which the prosopography and socio-political dimension of the ministers in those institutions would underscore part of colonial political action. ${ }^{17}$ By the same logic, but for Ecuador, Tamar Herzog's now classical work has become prominent as a social analysis in which legal culture intertwines with American Indian court daily praxis, which handed government over to subordinate sector and other political authorities. ${ }^{18}$

In Colombia's case, studies have mainly made reference to the reconstruction of experience as regards criminality, ${ }^{19}$ lawyers' lives ${ }^{20}$ and courtrooms in the passage to modernity - legal critical history, though, not having a strong influence here.

This is different when it comes to Brazil, the last space considered in this intellectual mapping, where the critical line of work has clearly penetrated through António M. Hespanha's work. In effect, the problems related to the separation of justice and administration, of sentence, punishment and pardon, can be found in volume 452 of the journal "Revista do Instituto Histórico e Geográfico Brasileiro" (2011). Once again, the discovery of the Ancien Règime logic allowed the legal historians to recover the experiences of the territories without appalling to the concept of state. A recent contribution on this topic shows a union between constitutional and political history, in which the thoughts of Hispanic-American critical history turn to Portuguese-Brazilian experience. ${ }^{21}$

These crossovers, which are sensitive to political conceptualization and to the grammars which created jurists' discourses and knowledge in pre-modern times, seem to weaken the beginning of the 19th century, when topics connected with security and law enforcement institutions (police force, prisons, the army, the military) start gaining ground as an exception within the rhetoric of freedom and equality underlying 19th century political discourse. It is there that, in connection with criminality, repression and the modern order culture, the new legal history would become hegemonic in Latin American studies. It is, then, important to survey some new lines, questions and dimensions developed by the new legal history in recent years.

\section{Security Institutions: Modernity's Interdisciplinary Field (19th and 20th Centuries)}

Foreign to all historiographic renewal mentioned above, the history of security and law enforcement institutions in Latin America was largely sponsored by each country's very own police forces until practically the end of the 20th century. ${ }^{22}$ This was so, not only due to the selfcelebratory need of said agencies to gain such historical path as could justify their actions in the present but also due to a marked historiographic disinterest in these studies. Until very recently, there have been prejudices which led the academic world to believe that using historical documents produced by those institutions irrevocably implied a justification of police practices, no matter what historical period they included. ${ }^{23}$ 
This view started to change in the 1980s, when the transition process from dictatorships to democracies takes place in Latin America. Human Rights Organizations began to do research in order to shed light on the various crimes committed by the military and police forces during the region's recent history. This is, thus, the way work was done that dug deep into the past of police institutions in order to explain the historical path which had led these state agencies to actively take part in the period of state terrorism. ${ }^{24}$ Toward the end of the 20th century, within the context of increasing debates about citizenship and public safety in Latin America and with the beginning of the police reform process in the region, greater interest developed in the historical studies of law enforcement institutions, which continued to receive contributions from other social sciences, such as anthropology and sociology. ${ }^{25}$

Conversely, in the English-speaking academic world, some authors who were doing research into the role of the police during 19th century Latin America's political regimes highlighted the importance that lay on the links between police institutions and political power and simultaneously pointed out key features of policing, social control and people's forms of resistance to police action. Such was Paul Vanderwood's case ${ }^{26}$ and his work on Mexican Porfiriato's rural police, and that of Thomas Holloway's, who studied Rio de Janeiro's police through much of the 19 th century. ${ }^{27}$

Added to these were contributions from Latin American historians. Initially, interest laid on the incidence that positivist ideas and technological change had on police modernization processes. Case studies, such as Marcos Luiz Bretas's pioneer work for Rio de Janeiro's police at the beginning of the 20th century, showed the limitations of such influence on an everyday basis. ${ }^{28}$ Therefore, almost simultaneously with the first professional organization attempts, at the onset of the 20th century, the need quickly arose for the implementation of reforms which could correct police inefficiency and corruption problems, which these new institutional models failed to solve. ${ }^{29}$

Some modernization effects in Latin America, such as criminality control, the 'social issue' (circa 1900) and the role that the police played in these, became the focus of attention for many historians. ${ }^{30}$ Their work contributed to enlarging our knowledge of lock-up and security institutions, especially at the end of the 19th century and the beginning of the 20th century. It was thus, then, that the topic agenda for a history of law enforcement institutions in Latin America became more and more diverse and enriched by new research results, especially through a systematic exploration of police archives. ${ }^{31}$

Benefiting from the historiographic advances of this field as well as from the New Legal History, recent works have eventually tackled 20th century Latin American police history. ${ }^{32}$ The most well-known contributions correspond to the countries where there have already been studies about the history of justice and new perspectives in legal history, namely: Mexico, Brazil, Chile and Argentina, as can be appreciated by this article's bibliography. With no intention to exclude other very valuable research from historians in other Latin American countries, we believe that it is in these four countries where a "corpus" of historical studies about the police can be found.

The themes are varied, though they focus on identifying the growing complexities of police institutions and their connection with other state agencies, with various civil social actors as well as with circuits of illegality, crime and political repression permeating diverse law enforcement agencies. Therefore, the history of security institutions in the 20th century establishes a dialog with the rest of the social sciences which study the police, democratic public safety and society's rights improvement. ${ }^{33}$

This road to the present time of the history of security and law enforcement institutions, marked by the abovementioned interdisciplinary agenda, operates around the consequences that modernity has had on police institutions and it somehow distances itself from the work 
of the New Legal History. We will now take the opposite path, arriving at the early 19th century once again. There we can find that historiographic crossroad we pointed out at the beginning of this article.

\section{The 19th Century: Debate and Meeting Point}

Based on the controversy between the history of the justice and the history of security institutions and taking into consideration temporalities which set out historiographic lines with an influence on Latin American thought, what is obtained is more than a simple historiographic tale, by establishing points of conflict with some perspective or another, when dealing with the 19 th century. In effect, given that the views on jurisdictions and security institutions take into account not only their institutional structure but also, rather, the ends they have: justice and safety; the new studies make a projection on a debate arena which has the crisis of jurisdictional logics and the statement that claims a modernization through social security, both police and prison-related, in the cross hairs.

As a consequence of that derivation of aims, at least three levels of analyses, which are always connected to one another, start to be delineated. The first, based on contending political languages, but drawing from a more anthropological current, comes to analyze the start-up of diverse acting logics in order to describe the rationalities of judicial institutions as opposed to those other institutions which develop toward the center of the police force and the penitentiary system. The second, which lies closer to cultural history issues, is in the spotlight of constitutional, political, institutional and journalist languages, at the crossroad between institutions and society, which can sense the legitimating channels that various groups' praxis has, in the complex social institution process of new agents and new orders. And lastly, there is a myriad of interests in the observation and description of social control devises, of practices shaped toward the center of the very institutions, professionalization attempts, and - above all - of social reactions and impact in the face of new legal-political webs, in the everyday life of the courtroom, police stations and prisons.

As a consequence of this field's qualitative and quantitative increase, the 19th century seems to be a lengthy century, one that goes from the last decades of the 18th century up to approximately 1910. In that long century, on the one hand, justice's legal and social history carefully measures and analyzes the impact that the codifying process, the shaping of the Judiciary, the creation of an administration, and so on, have had on the face of the strong prior experiences of jurisdictional logics, which, resulting from a tradition of centuries of praxis, do not appear to be easy to do away with. Therefore, the attempts to modernize security institutions also find political and material limits to the development of projects whose central axis lies on the idea of order.

Thus, where projects and prior experiences meet, the 19th century seems to break away from a modernizing linearity, including in the debate agenda various temporalities, discourses and ends which belong to judicial and security institutions. These elements enable a dialog that, far from finding completion, calls for greater studies in a rich field of constant crossovers, in which both political and constitutional spheres start to appear as records including an experience going through and projecting their issues on the 20th century.

We would like to highlight, then, the interest that lies behind historical research on this period, as in it there converge the contributions made by the New Legal History, the critical history of Law and the history of security institutions. After long individual paths and without abandoning those historical periods, which have been the focus of their attention, these three currents seem to find a meeting point in the 19th century to set about a move forward in Latin American historiographic studies, the growth of whose results we will witness in the next few years. 


\section{Short Biographies}

Osvaldo Barreneche. PhD in History (University of Arizona at Tucson). Professor of Latin American History at Facultad de Humanidades y Ciencias de la Educación, Universidad Nacional de La Plata and Independent Researcher at CONICET (Consejo Nacional de Investigaciones Científicas y Técnicas, Argentina). Has published Crime and the Administration of Justice in Buenos Aires, 1785-1853 (Lincoln, University of Nebraska Press, 2006) and the following edited volumes: with Andrés Bisso, Ayer, hoy y mañana son contemporáneos. Tradiciones, leyes y proyectos en América Latina (La Plata, Editorial de la Universidad Nacional de La Plata, 2010), with Angela Oyhandi, Leyes, justicias e instituciones de seguridad en la provincia de Buenos Aires (La Plata, FAHCE, 2012) and with Ricardo Salvatore, El delito y el orden en perspectiva histórica (Rosario, Prohistoria Ediciones, 2013).

Agustin E. Casagrande. PhD in Social Sciences (Universidad Nacional de La Plata). Assistant Professor at Facultad de Derecho y Ciencias Sociales, Universidad Nacional de La Plata and Research Fellow at CONICET (Consejo Nacional de Investigaciones Científicas y Técnicas, Argentina). Has published Los vagabundos y la justicia de Buenos Aires en el período tardo-colonial, 1785-1810 (Buenos Aires, INHIDE, 2012); currently a Research Fellow at Max Planck Institut für Rechtsgechichte, Frankfurt, Germany (2014-15).

\section{Notes}

* Correspondence: Universidad Nacional de La Plata, Calle 15A número 883 entre 464 y 465, City Bell, partido de La Plata, Código Postal: 1896, Argentina. Email: osvaldobarreneche@gmail.com

1 For example, that can be found in Zimmerman's early compilation of 1999: Zimmermann, Judicial Institutions in Nineteenth Century Latin America.

2 That can be appreciated in a close and comparative glance at the essays reunited in Aguirre et al., Reconstructing Criminality in Latin America; and in Salvatore et al., Crime and Punishment in Latin America. Law and Society Since Colonial Times.

3 As the recent studies inside the political history have suggested, the 19th century becomes crucial to comprehend the conflictive trespass from the old world to "the attempt" of creating a modern state and a political system inscribed inside the new political conceptuality, new devises of social control, etc.

4 As it has been suggested that re-dimension of legal studies could be presented, also, as a consequence of the arrival of new cultural perspectives, not only from anthropology (Geertz) but also from history (the case of E. P. Thompson) and philosophy (Foucault). See: Palacio et al., Justicia, Política y Derechos en América Latina: apuntes para un debate interdisciplinario,

5 Meanwhile, Grossi explained how an order without state functioned in medieval times; Bartolomé Clavero and António M. Hespanha made clear how other political institutions and diverse economies of punishment were the basis for ruling in pre-modern societies: family, grace, friendship, don, etc. see: Clavero,'Del estado presente a la familia pasada'; Clavero, Antídora. Antropología Católica de la Economía Moderna; Grossi, P., El orden jurídico medieval; Hespanha, La Gracia del Derecho: Economía de la Cultura en la Edad Moderna.

6 Garriga, 'Gobierno y justicia: el Gobierno de la Justicia'.

7 Frigo, '<<Disciplina Rei Familiariae > > a Economia como Modelo Administrativo de Ancien Régime'.

8 Quaderni Fiorentini, Storia sociale e dimensione giuridica; Dossier, 'Historia política e historia del derecho'.

${ }^{9}$ Mijángos y Gonzáles, El nuevo pasado jurídico Mexicano.

10 Speckman Guerra et al., 'Ley y justicia (Del Virreinato a la Postrevolución'.

11 Speckman Guerra et al., 'La justicia penal: estado actual de la investigación histórica'.

12 Tau Anzoátegui et al., El derecho local en la periferia de la Monarquía Hispana, Río de la Plata, Tucumán y Cuyo, siglos XVI-XVIII.

13 Barriera et al., La Justicia y las formas de la autoridad. Organización política y justicias locales en territorios de frontera. El Río de la Plata, Córdoba, Cuyo y Tucumán, siglos XVIII-XIX. Fradkin et al., La ley es tela de araña: ley, justicia y sociedad rural en Buenos Aires, $1780-1830$. 
14 Agüero, Castigar y perdonar cuando conviene a la República. La justicia penal de Córdoba del Tucumán, siglos XVII y XVIII.

15 Barriera, Abrir puertas a la tierra. Microanálisis de la construcción de un espacio político. Santa Fe, 1573-1640.

16 Chambers, From Subjects to Citizens: Honor, Gender, and Politics in Arequipa, Peru, 1780-1854.

17 De la Puente Brunke, J., 'Los Oidores en la sociedad limeña: notas para su estudio (siglo XVII)'.

18 Herzog, La administración como un fenómeno social: la justicia penal de la ciudad de Quito (1650-1750).

19 Patiño Millán, B., Criminalidad, ley penal y estructura penal en la provincia de Antioquía, 1750-1820.

20 Uribe Uran, V. Vidas honorables: abogados, familia y política en Colombia, 1780-1850.

21 Slemian et al., 'Em trajes brasileiros: justiça e constituição na América ibérica (c. 1750-1850)'.

22 Medina Balsa, Historia de la Policía Nacional; Rodriguez et al., Historia de la Policía Federal Argentina a las puertas del tercer milenio; Miranda, La Policía y Carabineros. Ensayos históricos y biográficos; Victoria Rodríguez, Evolución histórica de la policía uruguaya.

23 Sirimarco, Estudiar la policía. La mirada de las ciencias sociales sobre la institución policial.

24 Tiscornia, Activismo de los derechos humanos y burocracias estatales.

25 Gayol et al., Violencias, delitos y justicias en la Argentina; Mansilla, La policía boliviana. Entre los códigos informales y los intentos de modernización; Bailey et al., Public Security and Police Reform in the Americas; Galeano et al., Mirada (de) uniforme. Historia y crítica de la razón policial.

26 Vanderwood, Disorden and Progress. Bandits, Police and Mexican Development.

27 Holloway, Policing Rio de Janeiro. Repression and Resistance in a Nineteenth Century City.

28 Bretas, Orden na cidade. O ejercicio cotidiano da autoridade policial no Río de Janeiro: 1907-1930.

29 Barreneche et al., 'Notas sobre las reformas policiales en la Argentina, siglos XIX y XX'.

${ }^{30}$ Di Liscia et al., Instituciones y formas de control social en América Latina (1840-1940); Caimari, La ley de los profanos. Delito, justicia y cultura en Buenos Aires (1870-1940); Buffington et al., True Stories of Crime y Modern Mexico; Sozzo, Historias de la cuestión criminal en la Argentina; Salvatore et al., El delito y el orden en perspectiva histórica.

31 García Ferrari, Ladrones conocidos / Sospechosos reservados. Identificación policial en Buenos Aires, 1880-1905; Kahan, “Unos pocos peligros sensatos". La Dirección de Inteligencia de la Provincia de Buenos Aires ante las instituciones judías de la ciudad de La Plata; Caimari, Mientras la ciudad duerme. Pistoleros, policías y periodistas en Buenos Aires, 1920-1945; Cárdenas, El orden gañán. Historia social de la policía, Valparaíso 1896-1920.

32 Bohoslavsky et al., La policía en perspectiva histórica. Argentina y Brasil (Siglo XIX a la actualidad); Barreneche, 'De brava a dura. La policía de la provincia de Buenos Aires durante la primera mitad del siglo XX'; Palma Alvarado, 'Una historia en verde. Las policías en Chile. Balance y sugerencias para la investigación'.

33 Sapori, Securança pública no Brasil: desafios e perspectivas; Sain, El Leviathán Azul. Policía y política en la Argentina; Ungar, Policing Democracy: Overcoming Obstacles to Citizen Security in Latin America; Barreneche et al., Leyes, justicias e instituciones de seguridad en la provincia de Buenos Aires (Siglos XIX a XXI); Sabet, Police Reform in Mexico: Informal Politics and the Challenge of Institucional Change.

\section{Bibliography}

Agüero, A., Castigar y perdonar cuando conviene a la República. La justicia penal de Córdoba del Tucumán, siglos XVII y XVIII. (Madrid: Centro de Estudios Políticos y Constitucionales, 2008).

Bailey, J. and Dammert, L., (eds.), Public Security and Police Reform in the Americas. (Pittsburgh: University of Pittsburgh Press, 2006).

Barreneche, O., 'De brava a dura. La policía de la provincia de Buenos Aires durante la primera mitad del siglo XX', Cuadernos de Antropología Social. Sección de Antropología Social, Instituto de Ciencias Antropológicas, 32 (2010): 31-56.

Barreneche, O., and Galeano, D., 'Notas sobre las reformas policiales en la Argentina, siglos XIX y XX', Cuadernos de Seguridad. Consejo de Seguridad Interior. Ministerio de Justicia, Seguridad y Derechos Humanos, 8 (2008): 73-114.

Barreneche, O., and Oyhandy, A., (comp). Leyes, justicias e instituciones de seguridad en la provincia de Buenos Aires (Siglos XIX a XXI) (La Plata: Edulp, 2012).

Barriera, D., Abrir puertas a la tierra. Microanálisis de la construcción de un espacio político. Santa Fe, 1573-1640. (Santa Fe: Ed. Ministerio de Innovación y Cultura de la Provincia de Santa Fe y Museo Histórico Provincial "Brigadier Estanislao López", 2013).

Barriera, D. et al., La Justicia y las formas de la autoridad. Organización política y justicias locales en territorios de frontera. El Río de la Plata, Córdoba, Cuyo y Tucumán, siglos XVIII-XIX. (Rosario: ISHIR CONICET-Red Columnaria, 2010).

Bohoslavsky, E., Caimari, L., and Schettini, Cristiana, (coord.). La policía en perspectiva histórica. Argentina y Brasil (Siglo XIX a la actualidad) (Buenos Aires: UdeSA and UNGS, 2009). 
Bretas, M. L., Orden na cidade. O ejercicio cotidiano da autoridade policial no Río de Janeiro: 1907-1930. (Río de Janeiro: Rocco Editions, 1997).

Buffington, R. and Piccato, P., True Stories of Crime y Modern Mexico. (Albuquerque: University of New Mexico Press, 2009). Caimari, L., La ley de los profanos. Delito, justicia y cultura en Buenos Aires (1870-1940). (Buenos Aires: Fondo de Cultura Económica, 2007).

Caimari, L., Mientras la ciudad duerme. Pistoleros, policías y periodistas en Buenos Aires, 1920-1945. (Buenos Aires: Editorial Siglo XXI, 2012).

Cárdenas, V., El orden gañán. Historia social de la policía, Valparaíso 1896-1920. (Concepción: Ediciones Escaparate, 2013).

Chambers, S., From Subjects to Citizens: Honor, Gender, and Politics in Arequipa, Peru, 1780-1854. (Pensilvania: Pensilvania State University, 2011).

Clavero, B., 'Del estado presente a la familia pasada', Quaderni Fiorentini. Per la storia del pensiero giuridico moderno, 18 (1989): 583-605.

Clavero, B., Antídora. Antropología Católica de la Economía Moderna. (Milán: ed. Giuffré, 1991).

De la Puente Brunke, J., 'Los Oidores en la sociedad limeña: notas para su estudio (siglo XVII)', Temas Americanistas, 7 (1990): 21-35.

Di Liscia, M. and Bhohoslavsky, E., (eds). Instituciones y formas de control social en América Latina (1840-1940) (Buenos Aires: Editorial Prometeo, 2005).

Dossier História do Direito', Revista do Instituto Histórico e Geográfico Brasileiro, 452 (2011): 13-429.

Dossier, 'Historia política e historia del derecho', Revista Polhis, 10 (2012): 23-107.

Fradkin, R. et al., La ley es tela de araña: ley, justicia y sociedad rural en Buenos Aires, 1780-1830. (Buenos Aires: Prometeo Libros, 2009).

Frigo, D., ' $<<$ Disciplina Rei Familiariae $>>$ : a Economia como Modelo Administrativo de Ancien Régime', Penélope, Fazer e desfazer a história, 6 (1991): 47-62.

Galeano, D. and Kaminsky, G., Mirada (de) uniforme. Historia y crítica de la razón policial. (Lanús: Universidad Nacional de Lanús y Editorial Teseo, 2011).

García Ferrari, M., Ladrones conocidos/Sospechosos reservados. Identificación policial en Buenos Aires, 1880-1905. (Buenos Aires: Editorial Prometeo, 2010).

Garriga, C., 'Gobierno y justicia: el Gobierno de la Justicia', in Lorente, M. (dir.), La jurisdicción contencioso-administrativa en España. Una historia de sus orígenes (Madrid: Consejo General del Poder Judicial, 2009).

Gayol, S., and Kessler, G. (comp.) Violencias, delitos y justicias en la Argentina (San Miguel: Editorial Manantial y Universidad Nacional de General Sarmiento, 2002).

Grossi, P., El orden jurídico medieval. (Madrid: ed. Marcial Pons, 1996).

Herzog, T., La administración como un fenómeno social: la justicia penal de la ciudad de Quito (1650-1750). (Madrid: Centro de Estudios Constitucionales, 1995).

Hespanha, A. M., La Gracia del Derecho: Economía de la Cultura en la Edad Moderna. (Madrid: Centro de Estudios Constitucionales, 1993).

Holloway, T., Policing Rio de Janeiro. Repression and Resistance in a Nineteenth Century City. (Redwood City: Stanford University Press, 1993).

Kahan, E., "Unos pocos peligros sensatos". La Dirección de Inteligencia de la Provincia de Buenos Aires ante las instituciones judías de la ciudad de La Plata. (La Plata: EDULP, 2008).

Mansilla, H. C. F., La policía boliviana. Entre los códigos informales y los intentos de modernización. (La Paz: Editorial Plural, 2003).

Medina Balza, R., Historia de la Policía Nacional. (Editorial Calama: La Paz, 1990).

Mijángos y Gonzáles, P., El nuevo pasado jurídico Mexicano. (Madrid: Universidad Carlos Tercero, 2011).

Miranda, D., La Policía y Carabineros. Ensayos históricos y biográficos. (Santiago de Chile: Mutualidad de Carabineros, 2004).

Palacio, J. M. and Candioti, M., Justicia, Política y Derechos en América Latina: apuntes para un debate interdisciplinario. (Prometeo Libros: Buenos Aires, 2007).

Palma Alvarado, D., 'Una historia en verde. Las policías en Chile. Balance y sugerencias para la investigación', Revista Historia y Justicia, 2 (2014): 1-27.

Patiño Millán, B., Criminalidad, ley penal y estructura penal en la provincia de Antioquía 1750-1820. (IDEA: Medellín, 1994).

Quaderni Fiorentini, 'Storia sociale e dimensione giuridica', Biblioteca, 22 (1986): 3-465.

Rodríguez, A. E. and Zappietro, E. J., Historia de la Policía Federal Argentina a las puertas del tercer milenio. (Editorial Policial: Buenos Aires, 1999).

Sabet, D. M., Police Reform in Mexico: Informal Politics and the Challenge of Institutional Change. (Stanford: Stanford University Press, 2012).

Sain, M., El Leviathán Azul. Policía y política en la Argentina. (Buenos Aires: Editorial Siglo XXI, 2008).

Salvatore, R., Aguirre, C., and Gilbert J., (eds). Crime and Punishment in Latin America. Law and Society Since Colonial Times (Durham: Duke University Press, 2001).

Salvatore, R. and Barreneche, O. (eds.), El delito y el orden en perspectiva histórica. (Rosario: Prohistoria Ediciones, 2013).

Sapori, L. F., Securança pública no Brasil: desafios e perspectivas. (Editora FGV: Río de Janeiro, 2007). 
Sirimarco, M. (comp.) Estudiar la policía. La mirada de las ciencias sociales sobre la institución policial (Buenos Aires: Ediciones Teseo, 2010).

Slemian, A. and Garriga, C., 'Em trajes brasileiros: justiça e constituição na América ibérica (c. 1750-1850)', Revista de História, 169 (2013): 181-221.

Sozzo, M., Historias de la cuestión criminal en la Argentina. (Ediciones del Puerto: Buenos Aires, 2009).

Speckman Guerra, E. and Cárdenas Gutiérrez, S., 'La justicia penal: estado actual de la investigaciones histórica', in VV.AA (ed.), La situación actual del sistema penal en México. (México: UNAM, 2011).

Speckman Guerra, E. and Marino, D., 'Ley y justicia (Del Virreinato a la Postrevolución)', Historia Mexicana, 4 (2006): 1101-1104.

Tau Anzoátegui, V. and Agüero, A. (Coord.), El derecho local en la periferia de la Monarquía Hispana, Río de la Plata, Tucumán y Cuyo, siglos XVI-XVIII (Buenos Aires: INHIDE, 2013).

Tiscornia, S., Activismo de los derechos humanos y burocracias estatales. (Ediciones del Puerto: Buenos Aires, 2008).

Ungar, M., Policing Democracy: Overcoming Obstacles to Citizen Security in Latin America. (Baltimore: Johns Hopkins University Press, 2011).

Uribe Uran, V., Vidas honorables: abogados, familia y política en Colombia, 1780-1850. (Medellín: Fondo Editorial Universidad EAFIT, 2008).

Vanderwood, P., Disorden and Progress. Bandits, Police and Mexican Development. (Lincoln: University of Nebraska Press, 1981).

Victoria Rodriguez, J., Evolución histórica de la policía uruguaya. (Montevideo: Editorial Byblos, 2005).

Zimmermann, E. (ed.), Judicial Institutions in Nineteenth Century Latin America. (London: Institute of Latin American Studies and University of London Press, 1999). 